Journal of Educational Technology

$\&$ Online Learning

Volume 5 | Issue 1 | 2022

http://dergipark.org.tr/jetol

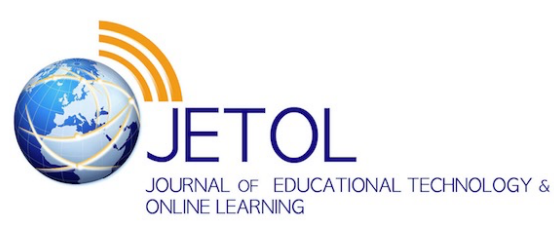

\title{
High school students' experiences with emergency remote teaching
}

\author{
Cigdem Han Tosunoglu ${ }^{\text {a }}$ (D), Selim Arslanoglu ${ }^{a}$ (D), Zeynep Balaban ${ }^{\text {a }}$ (D), Sule Eleman ${ }^{\text {a }}$ (D), \\ Esengul Kantekin a ${ }^{\text {DD }}$ \\ ${ }^{a}$ Marmara University, Turkey
}

Suggested citation: Han Tosunoglu, C., Arslanoglu, S., Balaban, Z., Eleman, S. \& Kantekin, E. (2022). High school students' experiences with emergency remote teaching. Journal of Educational Technology \& Online Learning, 5(1), 105-127.

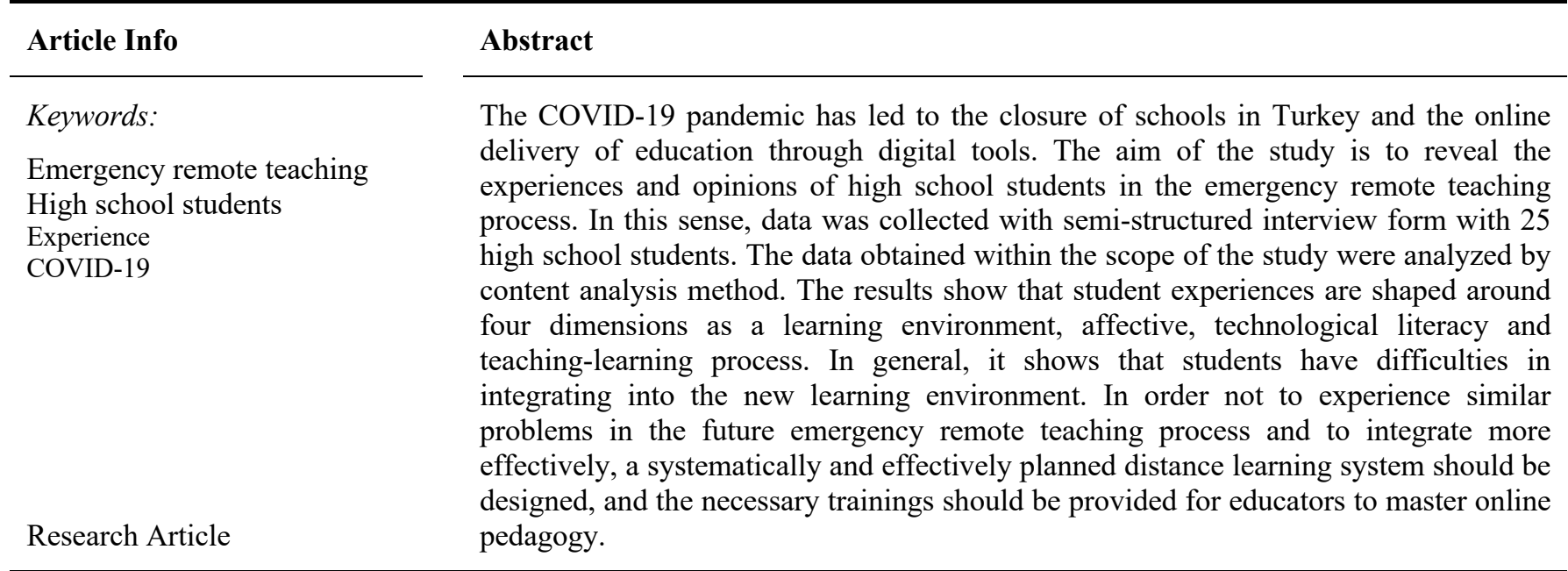

\section{Introduction}

With the spread of the COVID-19 virus in China, this process, which has been declared a global pandemic by the World Health Organization (WHO), has affected many areas around the world and caused significant changes in the dynamics of these areas. As a result of the pandemic, the current norms of education have changed along with many other areas such as health, culture, economy, etc. (Reiss, 2020). In the field of education, many countries around the world have announced the temporary closure of schools in response to the state of emergency to combat the spread of COVID-19. According to UNESCO's (2020) report; more than 1.9 billion students from 190 countries were forced to receive their education from face-to-face teaching to online form as part of measures to fight against the COVID-19 pandemic (Khlaif, Salha \& Kouraichi, 2021). This process was carried out by remote access using digital technologies as in other countries to prevent disruption of education and training activities in Turkey (Bakioğlu \& Çevik, 2020). When this process is carried out around the world, the primary goal is not to recreate a robust educational environment, but rather to ensure the continuation of education and training process quickly, reliably, and planning and implementation in an emergency or crisis (Hodges, Moore, Lockee, Trust \& Bond, 2020). For this purpose, solutions have emerged where the student has virtual access to the learning environment through online tools in order to continue the education processes quickly. One of these solutions, the method of educational processes created by the transition to online areas, has been discussed by experts that it cannot be called 'online learning' (Hodges et al., 2020). Therefore, a new concept of 'Emergency Remote Teaching' (ERT) concept block was used to describe online learning in crisis (Hodges et al., 2020). ERT is

\footnotetext{
* Corresponding author: Department of Biology Education, Marmara University, Turkey.

e-mail address: cigdem.han@marmara.edu.tr
} 
defined as an unplanned and abrupt transition from traditional face-to-face education to distance education using technology to provide teaching materials and activities due to natural disasters, economic crises, violence, and epidemics (Khlaif et al., 2021). Bozkurt and Sharma (2020) defined ERT as an alternative to the application of physically planned teaching materials, content and activities that occur only in times of disaster and crisis in the digital age, unlike normal online courses. ERT differs from normal distance education: While it takes 3-6 months to design, develop, and apply courses to students in typical distance education, ERT materials or courses are originally designed for face-to-face education and their efficiency may change when applied in distance education (Khlaif \& Salha, 2020). ERT is performed in synchronous or asynchronous environments using a variety of devices with Internet access.

Hodges et al. (2020) states that the main difference between online learning and emergency remote teaching is that online learning is due to careful teaching design and planning, and requires investment in an entire student support environment that takes time to build, whereas emergency distance teaching occurs as follows: ERT is a response to a crisis and requires a temporary shift of educational presentation to an alternative form of teaching, which involves the use of completely remote solutions for teaching that would otherwise be delivered face-to-face or using mixed courses.

Since ERT assumes that teaching will return to the original format when the crisis ends, its most important feature is that it is "temporary". Accordingly, the change in the educational process that occurred during the COVID-19 pandemic is defined as online teaching, but it is accepted that the concept of ERT better reflects this process, since it involves processes such as the emergence of a crisis, insufficient preparation, and improvisational rearrangement of courses for face-to-face education in applicable formats for the virtual classroom (Hodges et al., 2020; Brereton, 2021).

In a study conducted by Zhang, Wang, Yang and Wang (2020), the possible problems of ERT; uncertainty and disagreement about what to teach, how to teach, the workload of teachers and students, the impact of ERT on the teaching environment and educational equality; In order to overcome the potential challenges faced by politics such as the weakness of the online teaching infrastructure, the inexperience of teachers, the knowledge gap, the complex environment at home, etc., he discussed the thinking of equipping teachers and students with standardized home-based teaching/learning equipment, the teacher conducting education, and the inability to improve large online education. ERT's problems mentioned in this discussion have caused both teachers and students to have difficulty adapting (Shim \& Lee, 2020; Shamir-Inbal \& Blau, 2020). Studies have shown that in technology-related learning processes such as ERT, students' beliefs influence the application of the course, and students are reluctant and uninspiring to see the future in this form of education, and it has been emphasized that students attend classes like a stage audience only by watching (Wang \& East, 2020). Hammond et al. (2020), in a study that points to the difficulties experienced by students, found that students experienced the most problems with their Internet connections at ERT. Students' problems with technology or lack of reliable Internet may lead to a psychological-communication gap (Zilka, Cohen \& Rahimi, 2018). This situation confirms that Internet infrastructure is the basis of online training (Meyer \& Barefield, 2010).

Various studies that consider the negative features of online courses have shown that students may misunderstand assignments when lessons are not face-to-face, have difficulty when there are technical problems, and may be distracted by participating in activities that are not related to the course (Alexander, Truell \& Zhao, 2012). Another study has also shown that, unlike traditional university education, students are unable to attend online courses that require collaboration, that interaction between students and teachers is inadequate, and that students cannot participate in discussions with different groups of students (Dumford \& Miller, 2018). These problems in online courses may be similar because ERT is also performed remotely and using digital instruments.

Change of teaching and learning experiences by ERT has led to years of face-to-face students with no previous experience of distance learning facing online courses and digital worksheets (Çalık \& Altay, 2021). The forced transition to ERT has revealed that there are different dimensions in students' coping with this unprecedented educational process (Hodges et al., 2020). According to Means, Bakia and Murphy (2014), effective online learning, which is also preferred in ERT, has dimensions such as progress rate, 
student-teacher ratio, teaching methods, pedagogy, student role, teacher role, online communication synchronization, role of online assessments and feedback. According to Alveraz (2020), 4 dimensions were revealed in his study based on the learning environment in which 5 students exposed to ERT were examined in terms of their experiences: These dimensions include poor or lack of Internet access, financial constraints, lack of technological devices and lack of emotional support. With these dimensions, the effect of learning remotely in times of crisis was explained as follows: There are problems with access and affordability to basic teaching materials such as computer Internet, which are necessary for distance education, and there is also a concern about financial sustainability for these teaching materials, quarantines, fear of disease, uncertainty and lack of emotional support in line with the deterioration of the work-life balance of families negatively affects learning. Similarly, Aboagye, Yawson and Appiah (2020) demonstrated the dimensions that reduce the student's learning: (a) poor quality of online materials, (b) lack of clear learning objectives, (c) inadequate teachers in information transfer and (d) delay of course materials.

Another aspect that emerged in ERT's focus on student experiences was family support, and parents became controllers and facilitators of learning during the pandemic process, so their role changed compared to faceto-face teaching (Zhang et al., 2020). Students' inability to develop a sense of community in the learning environment and feeling isolated from the environment leads to decreased satisfaction with the course and difficulty in learning (Yates et al., 2021), and this result indicates the existence of an affective dimension of ERT. It is also stated that it is an important part of the learning process in ERT for motivation that can be evaluated to the affective dimension and is necessary for successful online learning (Lim, 2004; Khan, 2009). Shrivastay (2020) also suggested that factors such as motivation and participation in the course at ERT directly affected the achievements of the students. On the other hand, in distance education, students were seen as a tireless part of learning to work interactively and collaboratively with their peers by developing a sense of community (Wegerif, 1998) and emphasized the social nature of this learning environment dimension. Students are active in the process of determining their learning objectives, activities, needs and proficiency levels in the learning process together, thus taking more responsibility for their own learning (Eunjoo, 2006) and taking responsibility for learning for the students themselves positively supports the affective dimension of ERT. In the study conducted by Barker (2002), Baker mentioned the need to have sufficient software and hardware technical skills as well as online interaction skills that should be in both students and teachers in the development of availability in emergency remote teaching. This demonstrates the importance of student-student interaction and student-teacher interaction in the learning environment dimension of ERT. Gilbert (1999) emphasized that the student must have some basic knowledge of information technology in order to attend a course remotely. This emphasis makes it possible for ERT to infer that ERT gives rise to the dimension of the student's technological literacy. Wang and East (2020) emphasized the need for pedagogical innovations for ERT's curriculum within the scope of the learning and teaching process, and the need to uncover the curriculum in accordance with ERT can lead to the study of the learning-teaching process as an inclusive dimension.

Research shows that studies on the ERT process have different results in terms of students, teachers and other dimensions. In line with the literature, it is seen that these dimensions can be categorized as the dimension of the learning environment, the affective dimension, technological literacy and the learningteaching process. Evaluating these dimensions as components of a concept will allow us to better understand the concept of ERT. In this direction, the opinions and experiences of the students regarding ERT will be evaluated in line with this conceptual framework. The other important point of the study is that although the learning environment, affective variables, technological literacy needs and competencies of distance education in higher education have been studied in depth, distance education research in elementary and high school education is still very limited (Harris-Packer \& Segol, 2015; Huang, Shi \& Yang, 2021). Students directly affected by the ERT process caused by COVID-19 in particular have important ideas about the process and what they are going through and what they are experiencing. To effectively deal with possible future emergencies, to produce solutions and to prepare the educational process for such situations, what students think and experience about this process is necessary for an ideal ERT design (Robinson, Al-Freih and Kilgore, 2020). In this respect, the aim of the study is to reveal the 
opinions and experiences of high school students regarding the ERT process that has arisen in line with the COVID-19 pandemic.

\section{Methodology}

In this study, a qualitative research approach was adopted to reveal the views and experiences of students related to ERT. In line with this approach, data was collected with the help of a semi-structured interview form developed during the research process to reveal what students went through when they encountered a particular phenomenon and how they made sense of the situation. The inner world of an individuals is more clearly understood by the interview method (Briggs, 1986), which is most used in social sciences to gather information about people's views, experiences and beliefs (Patton, 1987).

\subsection{The context of study}

The COVID-19 virus appeared in the People's Republic of China in December 2019 and became an epidemic that affected the whole world in as little as four months after March 2020 (WHO, 2020a; 2020b). In Turkey, the first case of COVID-19 was found on March 11, 2020. Measures such as partial or full-time curfews, quarantine practices, social distancing and wearing masks have been taken all over the world to reduce the harms of the pandemic and slow its spread (Bozkurt, 2020). In this context, the COVID-19 Scientific Advisory Board has been established, guiding policymakers to support pandemic management in Turkey. With the recommendation of this board, as of the last week of March 2020, all K-12 level schools and universities were closed to face-to-face education and the content planned to take place over the Internet and television was moved to a rapidly prepared education system. Afterwards, the hybrid education system was implemented for a while. Students used to go to school two days a week and continued their education via distance education once a week. Then due to the increase in the number of cases, the 2020-2021 academic year continued through distance education. Synchronous learning carried out in high schools in Turkey. In this period, teachers access students by means of Zoom, Google Meet, Skype, etc. The data of the study were collected in April 2021 during this period when students continued their distance education.

\subsection{Participants}

The sample of the study consisted of 25 volunteer students studying at the secondary level in Istanbul. Students were selected in the context of the purposeful sampling. In addition to receiving compulsory training when determining participants, it was considered that they were at a level that could express themselves. Thirteen of the students were girls, 12 of whom were boys. The group included 10 students in 9th grade, 5 in 10th grade, 5 in 11th grade, 5 at 12th grade (Table 1). Interviews with these students lasted an average of 90 minutes over the Internet.

Table 1.

Participants

\begin{tabular}{cccc}
\hline Grade Level & Gender & & Total \\
\hline 9. & Female & Male & 10 \\
10. & 6 & 4 & 5 \\
11. & 1 & 4 & 5 \\
12. & 2 & 3 & 5 \\
All Levels & 3 & 2 & 25 \\
\hline
\end{tabular}

\subsection{Data Collection Tools}

A semi-structured interview form has been developed during the research process to reveal the views of students regarding ERT. Five $\mathrm{PhD}$ students and one field expert worked together to prepare this interview form. The research team first conducted a literature review of the ERT concept, history, size, and student context. As a result of the evaluation and discussions of the research, the dimensions and scale development questions of ERT were written. 


\subsection{Development of the interview in line with dimensions of ERT}

When the literature is examined, it is seen that four important dimensions emerged in the ERT process to reveal the experiences of the students. The first of the dimensions was determined as the dimension of the learning environment (Dumford \& Miller, 2018; Hammond et al., 2020; Shim \& Lee, 2020). In this dimension, the physical interactions of the student himself, the interactions he/she performed over the Internet during the ERT process and the technological competencies he/she had were considered as a subdivision. With ERT, the complete differentiation of the learning environment directly affects the educational process of the students by moving from a physical and face-to-face environment to a completely online environment. Secondly, the affective dimension was discussed (Kathleen \& Christopher, 2020; Yates Starkey, Egerton \& Flueggen, 2021). In this dimension, the sub-dimensions of interest, anxiety, motivation, adaptation, belonging, self-control, and time management were evaluated. On the affective level, attention was paid to the interaction of the student's own feelings, thoughts, and attitudes with ERT. The third dimension of the interview form constituted technological literacy (Barbour \& Reeves, 2009; Niemi and Kousa,2020). The sub-dimension of technological literacy was determined as the ability to use technological educational tools. This dimension emphasizes the capacity of students to benefit from emergency distance education. Fourthly, the dimension of the learning-teaching process was expressed (Barnett-Queen, Blair \& Merrick, 2005; Yates et al., 2021). This dimension was divided into three subdivisions: teaching methods, measurement evaluation and curriculum.

\section{Table 2.}

Student feedback form dimensions, objectives and sample questions related to ERT

\begin{tabular}{|c|c|c|}
\hline Dimensions & Objective & Sample Question \\
\hline Learning Environment Dimension & $\begin{array}{l}\text { It was aimed to determine how the } \\
\text { learning environment had an impact on } \\
\text { the student's learning experiences during } \\
\text { the ERT process. }\end{array}$ & $\begin{array}{l}\text { Do the people around you support you } \\
\text { during the lesson in emergency remote } \\
\text { teaching (ERT) or how? }\end{array}$ \\
\hline Affective Dimension & $\begin{array}{l}\text { During the ERT process, the aim was to } \\
\text { determine how the student affects the } \\
\text { learning process in terms of affective } \\
\text { variables such as anxiety, motivation, etc. }\end{array}$ & $\begin{array}{l}\text { Do you experience a sense of } \\
\text { procrastination and reluctance to enter } \\
\text { online classes at ERT? }\end{array}$ \\
\hline $\begin{array}{l}\text { Technological Literacy } \\
\text { Dimension }\end{array}$ & $\begin{array}{l}\text { In the ERT process, it was aimed to } \\
\text { reveal the impact of technology on } \\
\text { student experiences. }\end{array}$ & $\begin{array}{l}\text { Do you feel sufficient to use the } \\
\text { Internet to access information during } \\
\text { the ERT process? }\end{array}$ \\
\hline $\begin{array}{l}\text { Learning-Teaching Process } \\
\text { Dimension }\end{array}$ & $\begin{array}{l}\text { In the ERT process, it was aimed to } \\
\text { reveal the effect of differences in the } \\
\text { learning teaching process on the } \\
\text { experiences of students. }\end{array}$ & $\begin{array}{l}\text { What kind of assessment evaluation } \\
\text { system (test, homework, written) } \\
\text { should be in the courses during the } \\
\text { ERT process? Do your preferences } \\
\text { vary from course to course? }\end{array}$ \\
\hline
\end{tabular}

The objectives and sample questions related to the dimensions created as a result of the studies carried out by the research team are shown in Table 2 . The questions written in line with these dimensions were examined by the four field experts to ensure the content validity, and the research team revised this version in line with the feedback received. For example, in one of the revisions made on the affective level, the 
question "Are you interested in the courses in the ERT process?" was changed into the question, "How did your interest in the courses in the ERT process change compared to the courses in the face-to-face learning environment? Why?" based on feedback by the experts. This second version, prepared with the contribution of four different field specialists, was applied to 5 students as a pilot scheme. After this pilot application, a third version was created with feedback from students and practitioners. The question distribution by dimensions of the third, last version is shown in table 3.

Table 3.

ERT Interview Form Question Distribution by Dimensions

\begin{tabular}{ll}
\hline Dimensions & Question Numbers \\
\hline Learning Environment Dimension & $1-11$ \\
Affective Dimension & $12-26$ \\
Technological Literacy Dimension & $27-30$ \\
Learning-Teaching Process Dimension & $31-43$ \\
\hline
\end{tabular}

As a result, a semi-structured interview form with 43 open-ended questions in four dimensions was created.

\subsection{Analysis of Data}

The data obtained within the scope of the study were analyzed by content analysis method. In line with the content analysis, themes of students' views on the ERT process were obtained (Table 4). The analysis process started with transcription of the interview records. After the completion of the transcripts, five interview forms were independently encoded by three different researchers to ensure the inter-rater agreement (Patton, 2002). The themes obtained by different researchers were compared with each other, and it was determined that there was $74 \%$ fit. In line with the subsequent discussions, $100 \%$ consensus was reached. After this stage, the remaining 20 interviews were analyzed by three researchers, and the resulting code and themes were re-compared. Finally, the dimensions and themes in Table 4 were revealed. In the analysis process, the constant comparative method (Glaser, 1965) was used, which was repeatedly and retrospectively evaluated by the researchers.

The researchers evaluated each sentence that constituted the responses of the students in the relevant dimensions and collected these phrases under the appropriate themes. For example, the teacher support theme was created for the sentences "If I don't understand homework, my teacher answers privately when I ask my teacher." and "When there's something I don't understand, I can get information about it from my teachers instead of looking online." In addition, the researchers determined that the opinions and experiences of students during the analysis were positively and negatively separated in some dimensions, and the themes of these dimensions were presented negatively and positively.

Table 4.

Themes by Dimensions of ERT Interview Form Analyses

\begin{tabular}{|c|c|c|}
\hline Dimensions & Sub-Dimensions & Themes \\
\hline \multirow{4}{*}{$\begin{array}{c}\text { Learning } \\
\text { Environment }\end{array}$} & & Family support \\
\hline & & Technological infrastructure adequacy \\
\hline & & Teacher support \\
\hline & & In-class material sharing speed/effectiveness \\
\hline
\end{tabular}


Physical convenience of the learning environment

Friend cooperation/collaboration

Positive Aspects Practical/fast/later accessible learning environment

Course duration eligibility

School support

Lack of student teacher interaction

Lack of student-to-student interaction

Decreased learning environment efficiency

Negative Aspects Lack of technological and physical infrastructure

Inadequacy of course time

\begin{tabular}{|c|c|c|}
\hline \multirow{15}{*}{$\begin{array}{l}\text { Affective } \\
\text { Dimension }\end{array}$} & \multirow{4}{*}{ Positive Aspects } & Taking responsibility for learning \\
\hline & & Motivation to see lessons as a social space \\
\hline & & Self-Motivation \\
\hline & & Interest in online education \\
\hline & \multirow{11}{*}{ Negative Aspects } & Decreased interest in the course \\
\hline & & Uncertainty anxiety \\
\hline & & Decreased motivation due to lack of communication \\
\hline & & Reduced motivation due to online tools \\
\hline & & Lack of belonging to school \\
\hline & & Reluctance to course \\
\hline & & Low inner motivation \\
\hline & & Decreased motivation due to physical environment \\
\hline & & Decreased motivation due to technological deficiency \\
\hline & & Future anxiety \\
\hline & & Feeling of loneliness \\
\hline \multirow{2}{*}{$\begin{array}{l}\text { Technological } \\
\text { literacy }\end{array}$} & \multirow{2}{*}{$\begin{array}{l}\text { Using technological } \\
\text { educational tools }\end{array}$} & Sense of competence \\
\hline & & Use of online communication tools for educational purposes \\
\hline \multirow{9}{*}{$\begin{array}{l}\text { Learning } \\
\text { teaching process }\end{array}$} & \multirow[t]{4}{*}{ Education Methods } & Use of the lecturing method \\
\hline & & To use the Q\&A method \\
\hline & & To use the discussion method \\
\hline & & To use audiovisual methods \\
\hline & \multirow{3}{*}{$\begin{array}{l}\text { Measurement and } \\
\text { Assessment }\end{array}$} & Difficulties in measuring and assessing \\
\hline & & Low reliability of online assessment \\
\hline & & Effectiveness of Homework Applications \\
\hline & \multirow[t]{2}{*}{ Curriculum } & Curriculum and content structure is not suitable \\
\hline & & Curriculum and content structure conformity \\
\hline
\end{tabular}

\section{Results}

The aim of the research is to determine students' opinions regarding emergency remote teaching (ERT) that took place during the Coronavirus (COVID-19) pandemic. Student opinions in the research were presented 
with the help of frequency and percentage values in line with the dimensions and themes created during the analysis.

\subsection{Teaching-Learning Environment Dimension}

ERT is a process that has the dimension of planning and teaching the course, but also that students and teachers are not in the same physical classroom environment (Er-Türküresin, 2020), and that it is appropriate that the courses in the face-to-face training process are applicable online (Brereton, 2021). This dimension includes themes such as family, student, school and teacher communication, technological and physical equipment and infrastructure required for the learning environment, communication and information sharing between students, features of the learning environment and course durations affecting the students' teaching-learning process. With the analysis, it was determined that student opinions of this dimension were divided into positive and negative aspects. The positive aspects of the teacher-learning environment consisted of nine themes, and the negative aspects consisted of five themes (Table 5).

Table 5.

Teaching-Learning Environment Dimension Themes, Definitions, Frequency-Percentage Values and Citations

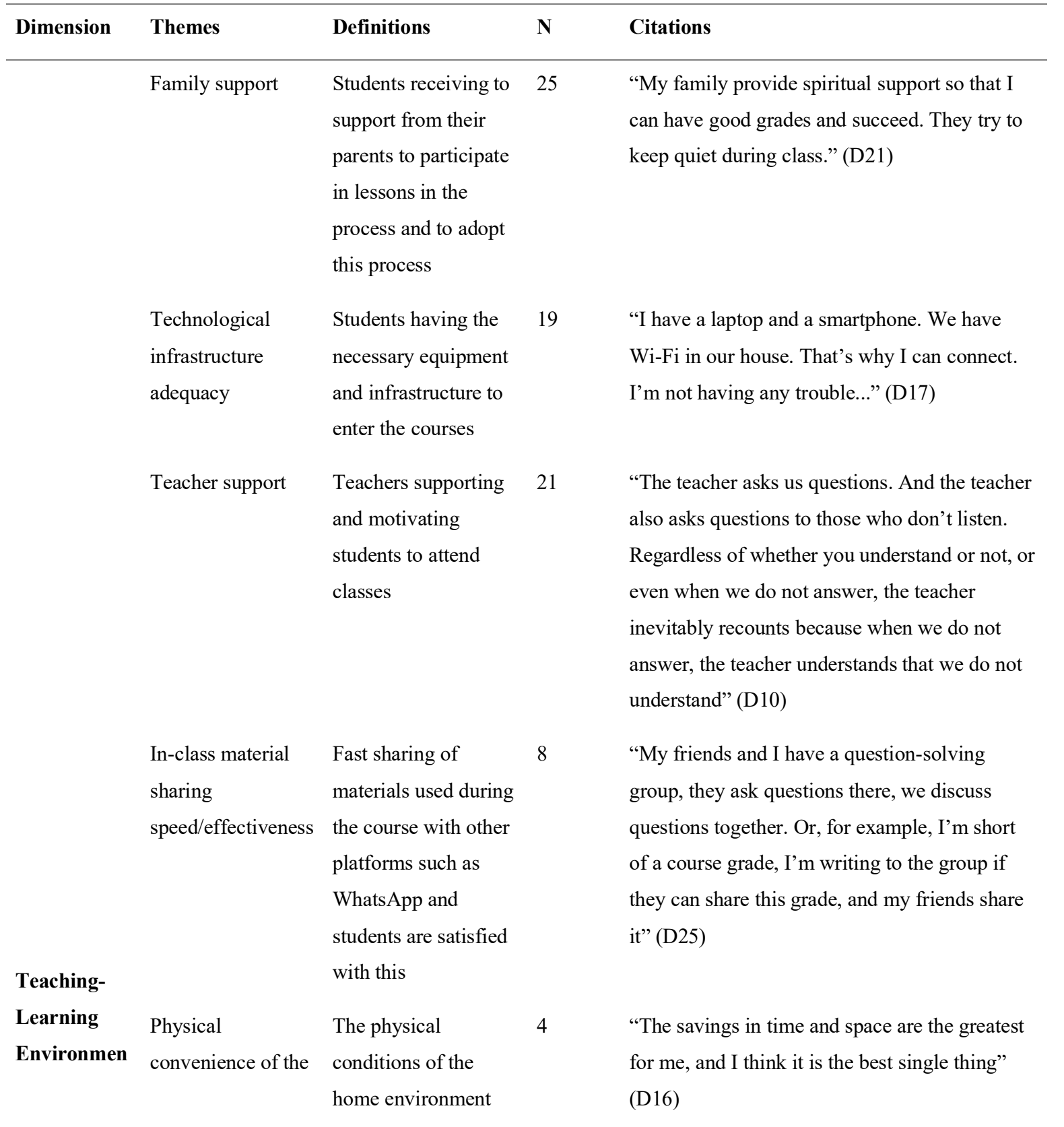




\begin{tabular}{|c|c|c|c|c|}
\hline \multirow{6}{*}{$\begin{array}{l}\text { t Positive } \\
\text { Aspects }\end{array}$} & \multirow{2}{*}{$\begin{array}{l}\text { learning } \\
\text { environment }\end{array}$} & \multicolumn{3}{|l|}{ are more comfortable } \\
\hline & & \multicolumn{3}{|l|}{ than in schools } \\
\hline & $\begin{array}{l}\text { Friend } \\
\text { cooperation/collab } \\
\text { oration }\end{array}$ & $\begin{array}{l}\text { Discussing the } \\
\text { subjects and } \\
\text { homework among } \\
\text { friends }\end{array}$ & 21 & $\begin{array}{l}\text { "I ask from WP or other social networks } \\
\text { whether there is anybody who understand the } \\
\text { subject..." (D4) }\end{array}$ \\
\hline & $\begin{array}{l}\text { Practical/fast/later } \\
\text { accessible learning } \\
\text { environment }\end{array}$ & $\begin{array}{l}\text { Fast access to online } \\
\text { courses with online } \\
\text { learning platforms } \\
\text { and, ability to access } \\
\text { these courses again } \\
\text { when necessary }\end{array}$ & 6 & $\begin{array}{l}\text { "My teacher shares with us in the school group } \\
\text { about assignments that we do not understand or } \\
\text { things that we do not know. Sometimes our } \\
\text { math teacher and biology and literature teachers } \\
\text { have already given us their phone numbers..." } \\
\text { (D9) }\end{array}$ \\
\hline & $\begin{array}{l}\text { Course duration } \\
\text { eligibility }\end{array}$ & $\begin{array}{l}\text { Appropriate } 30 \\
\text { minutes of course } \\
\text { durations }\end{array}$ & 13 & $\begin{array}{l}\text { "The time for math class is } 30 \text { minutes at our } \\
\text { school and I think that's enough. As a result, I } \\
\text { believe that the lessons are good with } 30 \\
\text { minutes" (D13). }\end{array}$ \\
\hline & School support & $\begin{array}{l}\text { Schools support } \\
\text { students in } \\
\text { curriculum, materials, } \\
\text { etc. }\end{array}$ & 20 & $\begin{array}{l}\text { "The support of our school is very good. All the } \\
\text { teachers take special care of us as if they were } \\
\text { our class teachers. They share our notes via } \\
\text { WhatsApp. They share the time of each course. } \\
\text { When we ask them something separately, they } \\
\text { answer immediately" (D7) }\end{array}$ \\
\hline \multirow{5}{*}{$\begin{array}{l}\text { Teaching- } \\
\text { Learning } \\
\text { Environmen } \\
\text { t Negative } \\
\text { Aspects }\end{array}$} & $\begin{array}{l}\text { Lack of student } \\
\text { teacher interaction }\end{array}$ & $\begin{array}{l}\text { Students interacting } \\
\text { less with their } \\
\text { teachers }\end{array}$ & 21 & $\begin{array}{l}\text { "I was actually interacting more with teachers } \\
\text { when the lessons were face to face..." (D24) }\end{array}$ \\
\hline & $\begin{array}{l}\text { Lack of student-to- } \\
\text { student interaction }\end{array}$ & $\begin{array}{l}\text { Students interacting } \\
\text { less with their friends }\end{array}$ & 21 & $\begin{array}{l}\text { "Negatively affected. Because my teacher is } \\
\text { also far away. I was seeing my friends at } \\
\text { school. Now we never see each other face-to- } \\
\text { face." (D8) }\end{array}$ \\
\hline & $\begin{array}{l}\text { Decreased learning } \\
\text { environment } \\
\text { efficiency }\end{array}$ & $\begin{array}{l}\text { Decreased efficiency } \\
\text { of the learning } \\
\text { process compared to } \\
\text { face-to-face }\end{array}$ & 15 & $\begin{array}{l}\text { "I think I'm performing } 50 \% \text { less...So I think } \\
\text { the performance is less" (D20) }\end{array}$ \\
\hline & $\begin{array}{l}\text { Lack of } \\
\text { technological and } \\
\text { physical } \\
\text { infrastructure }\end{array}$ & $\begin{array}{l}\text { Students having } \\
\text { problems with the } \\
\text { necessary hardware } \\
\text { and internet } \\
\text { connections }\end{array}$ & 15 & $\begin{array}{l}\text { "Our Internet is not fast enough sometimes I } \\
\text { can't get into classes..." (D22) }\end{array}$ \\
\hline & $\begin{array}{l}\text { Inadequacy of } \\
\text { course time }\end{array}$ & $\begin{array}{l}\text { Low lesson time of } \\
30 \text { minutes }\end{array}$ & 6 & $\begin{array}{l}\text { "I think it's inadequate. Because the teacher } \\
\text { usually waits for the first five minutes for the }\end{array}$ \\
\hline
\end{tabular}


When Table 5 is examined, the percentage values are seen with the answers (frequency) that the students give to the themes in the teaching-learning environment. Accordingly, the first noteworthy value is the expression of family support in positive aspects of the teaching-learning environment by all students $(100 \%)$. However, the themes of technological infrastructure adequacy $(76 \%)$, teacher support $(84 \%)$ and friend assistance/cooperation (84\%) were expressed at high value by the students. The theme of physical comfort of the learning environment is the least expressed theme $(16 \%)$. Negative vision values in the teaching-learning environment also attract a lot of attention. For example, the themes of a lack of student teacher interaction and a lack of student-student interaction have equal values and are quite high (84\%). However, the themes of decreased learning environment efficiency and lack of technological and physical infrastructure have equal value (60\%). The lowest value of this size belongs to the theme of inadequate course time (24\%). In the far-right column of Table 1, there are sample citations given by students to these themes.

The theme of family support, which is included in the positive aspects of the teaching-learning environment and has the highest frequency, is defined as "students receiving support from their parents to participate in lessons in the process and adapt to the process". The relationship of students with their families is one of the important issues that should be examined in this process (Sosa-Díaz, 2021). For example, the opinion of S11 on this subject is as follows: "They absolutely support it. For example, my mother follows my class hours especially well and, even if it is even a minute late, she comes to my room and checks that I attend the class."

With such statement, the student stated that he/she was supported by his family since the ERT process began and that he/she was very pleased with this situation. However, the theme of physical comfort of the learning environment with the lowest frequency among the positive aspects of the teaching-learning environment of the students is defined as "The physical conditions of the home environment are more comfortable than in schools". In this theme, ERT's possibility for studying flexibly regardless of time and classroom environment can be expressed as both preferable for students and an advantage for ERT (Bozkurt \&Sharma, 2020). For example, student S2's opinion in this dimension is as follows: "for example, I go online from bed at home; for example, I can eat food during course, I can do homework wherever I want, I can do it whenever I want." The student talked about the convenience of the class and the opportunities to study flexibly.

One of the themes with the highest frequency expressing the negative aspects of the teaching-learning environment is "Lack of student-to-student interaction". Some experts cited the lack of one-to-one face-toface interaction between individuals in the ERT process (Shin \&Hickey, 2021) and lack of communication (Yamamoto \& Altun, 2020). Therefore, this theme is an expected result. Student S3 indicated this situation;

"It affected us worse. I mean, teacher, I don't know, uh, so it's not the same as in the classroom environment. So, no one, my teacher, knows me, face to face... Well, when there's distance education, but when there's face-to-face training, at least we get to know each other."

In his statement, he/she emphasized the problem with the subject of knowing each other, which is especially problematic for ninth graders. In addition, the theme of inadequate course time with the lowest frequency among the negative aspects of the teaching-learning environment is defined as "Low course time of 30 minutes". Student S15 indicated his view in this dimension as follows;

"We learn what we can learn in 1 hour from normal face-to-face training in 2 hours at ERT. However, Both the Internet conditions and the teachers we live with, there is a waste of time due to situations where we do not understand each other clearly and what the teacher mean."

Here, the student emphasized that time losses negatively affect the course time. 


\subsection{Affective Dimension}

During the ERT process, many students had negative affective experiences. This has shown that students need affective support (Alvarez Jr, 2020) and affective success to have an effective and efficient learning process (Bozkurt, 2020). This dimension is the student's motivation to learn, motivation to see lessons as a social space, decreased interest in the course with positive themes such as self-motivation and interest in online education, decreased motivation due to uncertainty anxiety, lack of communication, decreased motivation due to online means, lack of belonging, reluctance towards the course, inability to self-motivate, decreased motivation due to physical environment, decreased motivation due to technological deficiency, future anxiety and feelings of loneliness. With the analysis, it was determined that student opinions were divided into positive and negative aspects. The affective dimension consists of a total of 15 themes, four positive and 11 negative themes.

\section{Table 6.}

ERT Process Affective Dimension Themes, Definitions, Frequency-Percentage Values and Citations

\begin{tabular}{|c|c|c|c|c|}
\hline Dimension & Themes & Definitions & $\mathbf{n}$ & Citations \\
\hline \multirow{5}{*}{$\begin{array}{l}\text { Positive } \\
\text { Aspects of } \\
\text { Affective } \\
\text { Dimension }\end{array}$} & $\begin{array}{l}\text { Taking responsibility } \\
\text { for learning }\end{array}$ & $\begin{array}{l}\text { Students planning and } \\
\text { taking responsibility for } \\
\text { their own learning } \\
\text { processes to increase } \\
\text { their success }\end{array}$ & 19 & $\begin{array}{l}\text { "... I listen to my teachers better, especially if I miss } \\
\text { what the teachers say, because of any difficulties, I } \\
\text { listen to the lessons online through other websites } \\
\text { with the facilities provided to us by the school. That } \\
\text { is why I have a responsibility to do so and I am } \\
\text { working on it in a good way..." S11 }\end{array}$ \\
\hline & $\begin{array}{l}\text { Motivation to see } \\
\text { lessons as a social } \\
\text { space }\end{array}$ & $\begin{array}{l}\text { Being motivated by the } \\
\text { course through } \\
\text { considering the course as } \\
\text { a socializing area }\end{array}$ & 2 & $\begin{array}{l}\text { "Between lessons that I do not normally talk to, I } \\
\text { can communicate more easily with my friends in the } \\
\text { chat section, and I can ask them what I need to } \\
\text { understand about something I do not understand" } \\
\text { (13 }\end{array}$ \\
\hline & Self-Motivation & $\begin{array}{l}\text { Students motivating } \\
\text { themselves towards } \\
\text { lessons (Self-motivation) }\end{array}$ & 2 & $\begin{array}{l}\text { "If I can ask the teacher what I do not understand } \\
\text { and the teacher can listen to me, I feel motivated." } \\
\text { S9 }\end{array}$ \\
\hline & $\begin{array}{l}\text { Interest in online } \\
\text { education }\end{array}$ & $\begin{array}{l}\text { Increased interest in } \\
\text { online education } \\
\text { compared to face-to-face } \\
\text { education }\end{array}$ & 4 & $\begin{array}{l}\text { "What if I think there is not much difference } \\
\text { between face-to-face training online because I am } \\
\text { normally a person who has a hard time listening to } \\
\text { lessons, and here we have an advantage here that } \\
\text { when our teachers ask, they can put more effort into } \\
\text { telling them better than they do face-to-face; that is } \\
\text { why I perform better." S13 }\end{array}$ \\
\hline & $\begin{array}{l}\text { Decreased interest in } \\
\text { the course }\end{array}$ & $\begin{array}{l}\text { Decreased interest of } \\
\text { students in lessons }\end{array}$ & 19 & $\begin{array}{l}\text { "I think it is definitely changed in a bad way because } \\
\text { in our classes at school, whether it is getting up in } \\
\text { the morning and getting ready for school or going to } \\
\text { school, I think we are going to class with a } \\
\text { preparation and something specific, which is } \\
\text { motivation..." S12 }\end{array}$ \\
\hline
\end{tabular}


Uncertainty anxiety

In the process, uncertainties experienced during education cause anxiety in students

$\begin{array}{ll}\begin{array}{l}\text { Decreased motivation } \\ \text { due to lack of } \\ \text { communication }\end{array} & \begin{array}{l}\text { Decreased } \\ \text { communication of } \\ \text { students and therefore } \\ \text { decreased motivation } \\ \text { towards lessons }\end{array} \\ \begin{array}{ll}\text { Reduced motivation } \\ \text { due to online tools }\end{array} & \begin{array}{l}\text { Decreased motivation } \\ \text { towards lessons due to } \\ \text { online communication } \\ \text { tools such as WP etc. } \\ \text { during the course process }\end{array} \\ & \begin{array}{l}\text { Students do not feel like } \\ \text { they belong in school }\end{array}\end{array}$

Negative

Aspects of

Affective

Dimension

Low inner motivation

Decreased motivation due to physical environment

due to technological
deficiency

Future anxiety
Students' inability to motivate themselves to study

Being unmotivated to the course due to other variables in the learning environment (sound, etc.)

Students are motivated during the course due to Internet connection problems, microphone interruptions, etc.

Students are concerned about not being successful, their future
"I am concerned by such uncertainties. I am already in my 12th grade, and we did not take the exams in this semester or in the 2 nd semester of the 11th grade in the previous semester and at first we have the fact of a diploma grade in the university exams. ..."S14

"Teacher, now that we are at home, there is no one, at least it would be better if we could see a few people..." S4

“... If I have written to someone like that in class and missed class, I am mad at myself after class. I missed it, for example, why are you doing such stupid things in the middle of class..." S25

"No. I just started school, and I do not feel the school atmosphere at all. Distance education is not like school" S22

"Yes, I do because I am not physically in the same environment when I am in class on the Internet, I have a lack of motivation to attend classes because I do not have to be in the same environment ..." S15

"My teacher, I can say that, when I do not understand the subject or answer a question incorrectly, my self-confidence decreases. Sometimes I get out of class...” D8

"Because we are at home, there can be knocking on doors, there can be a sudden noise, so there are certain conditions that we do not have, and from time to time, they can cause negativity."

"When my Internet slows down, when I leave class, it is hard to understand that subject again. Every time my Internet slows down, my motivation decreases." S24

"My teacher worries about the future, of course... Now that I am away, I cannot get in, and some classes are worried that I am lacking behind on the subject...." S4 
educational lives and

exams

Feeling of loneliness

Students feeling lonely

\author{
"I feel negative, to be honest. ... There is no longer a \\ friend environment where you can share everything \\ like this" S25
}

According to Table 6, the affective dimension themes of the students in the ERT process are especially focused on the negative side. The highest frequency theme in the positive direction of this dimension is to take responsibility for learning (76\%). On the other hand, at the lowest frequency, motivation to see lessons as a social field and self-motivation (8\%) themes were determined. In the negative aspect of this dimension, the contact with the highest frequency decreases interest in the course $(76 \%)$, while the contact with the lowest frequency is the low intrinsic motivation (16\%).

It is the responsibility of students to learn the contact with the highest frequency within the positive aspects of the affective dimension. This theme is defined as "Students planning and taking responsibility for their own learning processes to increase their success". In the ERT process, the greatest responsibility for learning falls to the student. In this process, it is very important to develop skills such as planning, selfcontrol, questioning and research (Bozkurt, 2020). In this dimension, the opinion of student S17 is as follows:

“... As I said about responsibilities, you have to support it very well by working on your own. Because distance education is not as efficient as face-to-face training. I think I am good at working on my own. I made a weekly plan. Of course, although there are studs, there are not going well, I am able to implement this program in general."

The student stated that he took good responsibility for learning in this process and directed the learning process by making his own lesson plan to support this. One of the themes with the lowest frequency, which is found in the positive aspects of the affective dimension, is self-motivation. It is known that student motivation decreases during the ERT process (Wilcox \& Vignal, 2020). For this reason, it is very important to ensure the continuity of the motivations of the students during the ERT process. For this purpose, students should question, review, and review their motivations in the learning process (Uçar \& Kumtepe, 2016). This opinion is supported by a student (S7) as follows:

"Motivating situations are my goals. I set myself a goal in the future. I work harder and get that goal."

With this statement, the student stated that he/she provided his own motivation with the goals he set. According to Table 6, there are many negative themes of the affective dimension. Accordingly, the highest frequency belongs to the theme of decreased interest in the course. During the ERT process, it was determined that the students' interest in the learning process, i.e., the courses, decreased (Kong \& Lee, 2021). Statement of student S2 regarding this theme is as follows:

"Yes, I think it is negative because I do not think it is as efficient as it was at school"

The student compared his interest in the course in the ERT process with the courses in the school and stated that his interest in the course was negative due to the ineffectiveness of the courses.

The theme with the lowest frequency in the negative aspects of the affective dimension is the low intrinsic motivation. In this theme, student S8 expressed his opinion as follows:

"My teacher, I can say that, when I do not understand the subject or answer a question incorrectly, my selfconfidence decreases. Sometimes I get out of class..."

This student stated that his inner motivation (Trigger \& Korkmaz, 2018), which allows the individual to take action in order to achieve a goal, decreased when he did not understand the question or answered it incorrectly, and therefore he left the course. 


\subsection{Technology Literacy Dimension}

Computer use and Internet technology have improved greatly, especially in the last 50 years. These technologies have been indispensable in many fields such as daily, business and education. This dimension refers to the proficiency of the technology literacy that students have, their ability to use online communication tools to access information during the education process, as well as to benefit from online education platforms. As a result of the analysis, this dimension consisted of two themes (Table 7).

Table 7.

ERT Process Technology Literacy Dimension Themes, Definitions, Frequency-Percentage Values and Citations

\begin{tabular}{|c|c|c|c|c|}
\hline Dimension & Themes & Definitions & $\mathbf{n}$ & Citations \\
\hline $\begin{array}{l}\text { Technology } \\
\text { Literacy }\end{array}$ & $\begin{array}{l}\text { Sense of } \\
\text { competence }\end{array}$ & $\begin{array}{l}\text { Students feel } \\
\text { technologically } \\
\text { knowledgeable } \\
\text { and adequate to } \\
\text { attend classes }\end{array}$ & 21 & $\begin{array}{l}\text { "I have stated that I have sufficient } \\
\text { knowledge and knowledge in technology, } \\
\text { and I do not think that I have any difficulty in } \\
\text { using the Internet and doing research on this } \\
\text { subject" (S18) }\end{array}$ \\
\hline Dimension & $\begin{array}{l}\text { Use of online } \\
\text { communication } \\
\text { tools for } \\
\text { educational } \\
\text { purposes }\end{array}$ & $\begin{array}{l}\text { Using online tools } \\
\text { for educational } \\
\text { purposes during } \\
\text { and after the } \\
\text { course }\end{array}$ & 25 & $\begin{array}{l}\text { "We use WP a lot already, especially when } \\
\text { we send a question to our teachers, not only } \\
\text { our friends, but also our friends when sharing } \\
\text { something or using video calls" (S12) }\end{array}$ \\
\hline
\end{tabular}

Table 7 first displays the percentage values of the students with their answers (frequency) to the themes of technology literacy. Accordingly, the first notable result is that no negative opinions are found in this dimension. However, it is seen that all students agree especially on the theme of "Use of online communication tools for educational purposes" (100\%). Finally, it can be said that the students have a very high sense of proficiency in using their technological literacy (84\%). Secondly, Table 3 has excerpts from the students.

The theme of "Use of online communication tools for educational purposes", which has one of the highest frequencies of technology literacy of students, is defined as "Use of online tools for educational purposes during and after the course". In the ERT process, teachers use a variety of online tools to support students' learning and communicate with students (Kaiper-Marquez, Wolfe, Clymer, Lee, McLean, Prins \& Stickel, 2020).

In addition, this theme refers to the interconnected communication of students and teachers with each other and with course contents during the distance education process (Y1ldiz \& Seferoğlu, 2020). Student S6 indicated on this theme;

"Yes. Sometimes some of us do not see the links in EBA. We are throwing him into our WhatsApp groups. Or we cannot solve some questions and we throw them into WhatsApp groups."

In his statement, S6 described the process of exchange of information with each other with friends with online tools. The theme of "Sense of proficiency" in the dimension of technology literacy of students is defined as "Students feeling technologically knowledgeable and sufficient to attend classes". In this theme, student S12 indicated as follows;

"... The reason you think it is enough because I can follow the lessons in a very good way. Here I am, throwing away my homework for my teachers. When teachers throw something at me, when they throw a document at me, I can open it, I can download it..."

S12 stated that he/she was technologically competent, and he/she knew how to use it. 


\subsection{Teaching-Learning Process}

Due to the Coronavirus (Covid-19) pandemic, face-to-face education was suspended in many countries, especially Turkey, and formal education was switched from open and distance education. In this process, especially technological preparation and teaching and learning process have been given importance in ensuring an effective and efficient education for everyone (Can, 2020). This dimension consists of three sub-dimensions: methods in the teaching-learning process, measurement evaluation and curriculum. In the subdivision of teaching methods, among the themes such as the use of flat narration method, the use of question-and-answer method, use of the discussion method, use of visual and auditory methods; there are themes of difficulties in measuring and evaluating the subdivision and evaluation, low reliability of online evaluation, effectiveness of homework practices and curriculum and subject content structure in the curriculum subdivision. The size of the teaching-learning process consisted of a total of nine themes (Table 8).

\section{Table 8.}

ERT Process Teaching-Learning Process Size Themes, Definitions, Frequency-Percentage Values and Citations

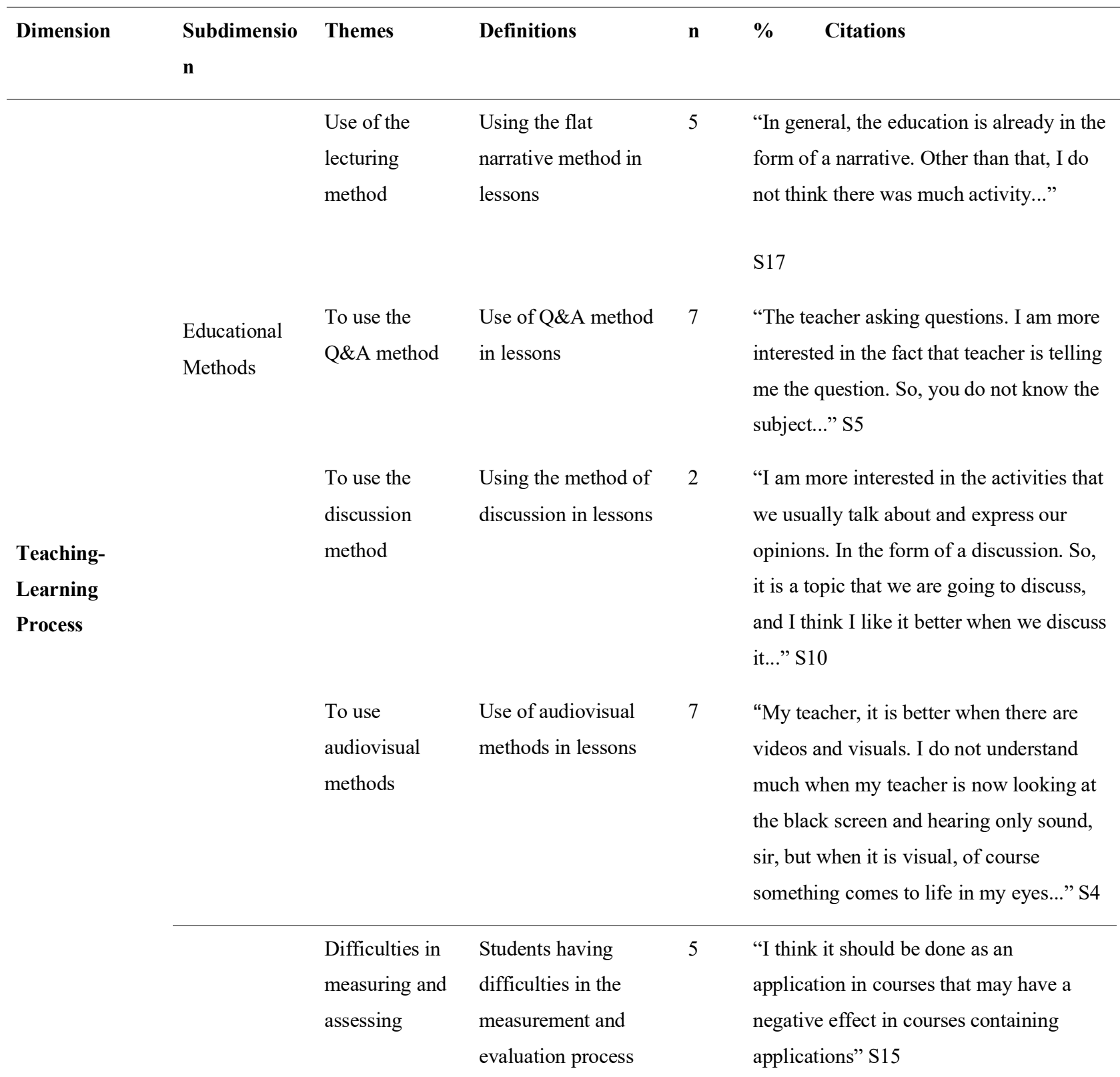




$\begin{array}{ll}\text { Low reliability } & \text { Students not trusting } \\ \text { of online } & \text { online measurement } \\ \text { assessment } & \text { and assessment }\end{array}$

Measurement

and

Assessment

Effectiveness of Students considering

Homework homework practices

Applications as very effective

17

..."it depends on the lesson. It could be

verbal, for example. Everybody turns on their camera. After all, when you look at that paper, it is clear that he is looking at it. In a way that everyone opens their camera... Because it is the test, I mean, because we cannot go to school...” S25

16

"I am definitely thinking about it.

Because, as I said, I think it was more

valuable to take notes, to do homework, to do research, because we are at a time when our individual efforts affect us more than face-to-face education." S16

"I think it needs to be mitigated even more because I cannot focus as much on a difficult issue here as we do face-toface..." S13

"I think it should be applied to the subject content and curriculum. Because it is not a problem, even in ERT...” S11

Table 8 includes excerpts, themes, percentage, and frequency values for the teaching-learning process of students. This dimension was divided into three sections, different from other dimensions. These sections included: teaching methods, measurement and evaluation process, and curriculum. When Table 4 is generally examined, it can be seen that the highest frequency is in the theme of "Low online evaluation reliability" (68\%). In general, more than half of students agree on this issue. However, the themes "Curriculum and subject content structure conformity" and "Use of the discussion method" have the lowest frequency (8\%). Only two students agree on this theme. One of the highlights of Table 4 is related to the curriculum section. The two themes in this section are opposites. With the analysis, it is seen that while a majority of the students $(60 \%)$ expressed opinions on the theme of inappropriate curriculum and subject content structure in the ERT process, only two students gave their opinions regarding the theme of curriculum and subject content structure conformity $(8 \%)$.

\subsection{Educational methods}

As in face-to-face education, the relationship between student-teaching and student-content is important in the ERT process. The relationship between student and teacher helps students understand the course contents in the teaching-learning process. For this reason, the high interaction between these variables is important in improving the quality of the learning-teaching process. In this context, there are student opinions about the use of audio and visual methods together with the flat narrative, Q\&A, discussion methods used in the teaching-learning process in ERT. The theme of "Using the question-and-answer method" with high frequency in this section was defined as "Using the Q\&A method in the courses". Student S6 stated the preference about the method used in the course with the view that "Q\&A activities are of more interest to us" about this theme. 


\subsection{Measurement and Evaluation}

In the ERT process, the reduction of face-to-face communication and interaction between individuals has resulted in significant limitations. Especially the disconnections of communication between the students and their teachers, the ineffectiveness of measuring and evaluating are among the important problems. It is also stated that measuring and evaluating is a challenging situation (Hodges \& Barbour, 2021). The theme of "Low online assessment reliability" with the highest frequency by analyzing students' opinions is defined as "students' lack of confidence in online measurement and valuation". In this context, student S9 stated as follows:

"Teacher, I do not think testing and writing will work very much in distance education. Commuting to school is different, but in such distance education, students can learn the answer over the phone, and I think other students are being treated unfairly."

With this view, the student emphasizes the problems in the measurement and evaluation process, especially due to the lack of face-to-face communication.

\subsection{Curriculum}

It has been determined that there are problems in the full implementation of the curriculum in online courses at ERT, and that there are difficulties in learning some courses because they do not allow to practice in ERT (Demir \& Kale, 2020). For this reason, it is stated that the curriculum should be converted into an online environment (Mohmmed, Khidhir, Nazeer \& Vijayan, 2020).

With the analysis carried out in this context, the theme of the curriculum and subject content structure not being suitable, and the theme of curriculum and subject content structure conformity were obtained together. In addition, the "curriculum and subject content structure conformity theme" is defined as "students thinking that the subject and content of the curriculum are in accordance with the ERT". Regarding this theme, student S18 indicated:

"Yes, I think it should be applied to the same as what we see in face-to-face training, but it is impossible to implement some application-based courses in the process of distance education, we can facilitate this with the help of various materials and the Internet".

The student stated that the curriculum must be applied exactly online and that there is a problem especially in courses that require practice.

\section{Discussion}

Disruption of education is not limited to pandemics; natural disasters such as earthquakes, wars and internal conflicts can also disrupt the educational process. It is very important to research students' ideas and experiences to have an idea of how we can create a more effective learning environment for students during such disruptions. With what we have learned from the context of COVID-19, we can become more prepared for future situations. In this context, the opinions, and experiences of high school students regarding the ERT process that emerged in line with the COVID-19 pandemic were examined. Accordingly, the opinions and experiences of the students regarding ERT will be discussed under four different dimensions.

The results of the study revealed that students received significant support from their parents, teachers, schools, and peers in adapting to the new learning environments they encountered, unlike school. It is a theme that has been emphasized by all family support participants. This theme, which is not much needed in other forms of distance education, is based on the provision and support of parents to provide and support the appropriate environment for their children to attend classes on a regular basis. According to Durak (2014), there is a high correlation between students' attendance levels and their success scores in the online learning environment. In this case, family support is considered an important variable that determines success in the ERT process. Another important result is that it contributes greatly to the learning processes of the opportunities to quickly access, share and re-watch teaching materials in the learning environment that arises with ERT compared to face-to-face education. According to Alexander, Truell and Zhao (2012), 
students are pleased with the flexibility, convenience and easy-to-reach experiences offered by online education. This convenience offered by my online learning environments can positively affect the academic success of students (Shim \& Lee, 2020).

The most negative experiences of students with the highest frequency related to the new learning environment are the decrease in communication and interaction between both their teachers and peers, which negatively affects them. However, students say that educational efficiency decreases during the ERT process compared to face-to-face education. The results of Shim and Lee's (2020) study with university students during the ERT process has shown that students evaluate the "interactioné experience both negatively and positively. Shim and Lee's study has revealed that on the one hand, students do not experience the tension and concerns of the process of asking questions and attending classes in face-to-face classrooms in online lessons during the ERT process and interact easily with their teachers through chat rooms. The results of the same study show the lack of student-teacher interaction as one of the most important negative variables in the ERT process. They show that listening to lessons from video recordings, lack of quick and deep interaction with the teacher in the course process are among downsides of this process. According to Kathleen and Christopher (2020), the most important driving force of the intellectual development of students is their peers in the same class, which disappears in online education. Therefore, measures should be designed to ensure smooth interaction between peers through online tools, and attention should be paid to the development of teachers' ability to manage such interactions.

Technological competence, which is one of the most important components of the new learning environment, appears in both negative and positive themes of the learning environment dimension. $76 \%$ of students reveal that they have sufficient materials, especially hardware, but $60 \%$ find that the learning process is directly negatively affected when the Internet connection is not efficient (Shim \& Lee, 2020). One of the most important determinants of students' academic success in this learning environment that arises with ERT is that they have the necessary tools to access the courses. At the same time, Internet connectivity in the process of online learning is a means of both distributing educational materials and continuing interaction between teachers and students (Trentin, 2007). At this point, access to the necessary educational materials and Internet infrastructure should be taken into consideration in order to ensure that students' academic achievements are not adversely affected by their economic situation in the ERT environments that will come up in the future.

The most obvious experience that students experience in the ERT process is that they develop themselves to take on their own responsibilities in the learning process. Alexander, Truel \& Zhao (2012) emphasizes that self-discipline is an important component for success in online learning environments. A significant majority of students have taken steps to identify and address their own learning needs in this process. In a similar study conducted in New Zealand, Yates, Starkey, Egerton and Flueggen (2021) found that high school students struggled to manage their learning processes with the idea that they lacked teacher control and had too much freedom. The difference between the students of these two countries may be due to the structure of the education system and especially the form of the university entrance exam. The central exams prepared by post-high school students in Turkey may have caused them to have higher selfdiscipline.

The negative experiences experienced by the student are quite diverse. Students have shown that their interest in courses decreased significantly during the ERT process. They explain this lack of motivation and interest in the courses from the distraction of online communication tools, the conditions of the home environment, the lack of communication in the online environment. Yates et al. (2021) also revealed that one of the most important challenges in this process is the lack of motivation of the students. One of the most important variables to increase the effectiveness of the ERT process is to support student motivation. For this reason, it is very important to use technology well and provide one-to-one feedback on assignments/tasks given to students (Yates et al., 2021). It is also important to integrate course materials into technology and to use special materials compatible with online education, such as ERT (Ng, 2019).

Students have stated that uncertainties about whether the education they receive during the ERT process is sufficient to prepare them for the university exam and how the exams will take place increase their anxiety 
levels. Approximately half of the students who participated in the study during the ERT process for about 1.5 years stated that they do not feel belonging to any educational institution, but also feel quite alone due to lack of communication in the home environment. Kathleen and Christopher (2020) found that in the case of ERT, students did not feel like they were involved in a course, as well as their academic achievement in the courses decreased. Therefore, it is necessary to choose the learning teaching approaches and practices suitable for ERT that will make students feel in a classroom and school environment. The most important feature of such approaches should be to ensure the active participation of the student in the course and to make the student feel mentally in the classroom (Schlesselman, 2020; Shim \& Lee, 2020).

The most important feature of technology literacy dimension is that most students feel technologically knowledgeable and adequate. Students' proficiency in this dimension is one of the most important components for the ERT process. Because the adequacy of individuals in technological literacy has a decisive role in the effective and successfulness of ERT. Barbour and Reeves (2009) argue that students need to have a high level of digital literacy in order to find and use information about their courses and communicate with others through technological devices. Unlike the results of this study, Baczek et al. (2021) found that approximately 54\% of medical students experienced problems with information technology and these problems were more common in students in the early years of higher education. Similarly, Niemi and Kousa (2020) found that during the ERT process, students at a high school in Finland experienced technical problems during their online exam practices. These results may be due to the high experience of students using technological tools due to the digital transformation taking place in schools in Turkey. However, in order for students to adapt quickly to future ERT situations, digital learning environments must be adapted to the normal educational process and different learning experiences must be presented for students to use technology effectively.

The teaching and learning process dimensions consists of the sub-dimensions such as teaching methods, measurement and evaluation, and curriculum. In terms of teaching methods, it is seen that different methods are used from the ERT process, but the "discussion" approach with the highest interaction with the student is preferred quite little. Contrary to teachers' preferences in the ERT process, some studies show that the way of discussion in online learning environments is quite effective (Barnett-Queen, Blair \& Merrick, 2005). It is even emphasized that well-managed online discussion environments are more organized and highly motivating by students than in the classroom environment (Yates et al., 2021). This situation shows that one of the most important deficiencies in the ERT process is the lack of communication and interaction.

In the lower dimension of measurement and evaluation, the most emphasized feature about ERT is that the measurement evaluation approaches that take place in this process are not trusted and the students are not subject to an objective evaluation. In online exams, students have concerns about their own proficiency and the distinctiveness of these exams. However, the students stated that homework practices are effective in terms of measurement evaluation in this process and that they better demonstrate their skills in a course with the help of assignments. Means et al. (2014) emphasize that the evaluation and feedback process is a very important variable in determining the effectiveness of online learning environments. In the lower dimension of curriculum, a significant majority of students have demonstrated that an approach that offers new learning experiences such as ERT is difficult to implement with a curriculum prepared for face-to-face education and that it would be more effective to prepare a curriculum specific to this process.

The results of this study give insight into how we can increase the effectiveness of ERT environments that are currently partially ongoing in different parts of the world or are likely to occur later. In general, it shows that students have difficulties in integrating into the new learning environment. Supporting pedagogies can be used to ensure that students be quickly integrated into this process. Supportive pedagogy should include clear guidelines, guidance on time management, empathy, well-managed discussions, different sources of multimedia, fun collaborative activities, unique experiences (Yates et al., 2021). An important first step in supportive pedagogy is to prepare students to be independent and take responsibility for their own learning. 


\section{Conclusions and Implications}

The data on students' perceptions of ERT in this study indicate that students have difficulties adapting to the new educational situation. Especially the lack of peer and student-teacher interaction negatively affects the students' interest and achievement in the lessons. Also, it seems that students did not trust online measurement and assessment methods. In general, students prefer to achieve quality academic progress and maintain their social and emotional wellbeing. In addition, it should be noted that the senior high school students' level of future anxiety increased throughout ERT process, but this situation provides to them take more responsibility for their own learning. Consequently, a more systematic and effectively planned distance learning system should be designed to overcome the negative student experiences associated with ERT presented in this study, and educators should be given the necessary training to master online pedagogy (Bozkurt et al., 2020).

\section{Acknowledgments}

We would like to thank to Ertugrul Ali Yavuz for his generous help in this study.

\section{References}

Aboagye, E., Yawson, J. A. \& Appiah, K. N. (2021). COVID-19 and E-learning: The challenges of students in tertiary institutions. Social Education Research, 2(1), 1-8.

Alexander, M. W., Truell, A. D.\& Zhao, J. J. (2012). Expected advantages and disadvantages of online learning: Perceptions from college students who have not taken online courses. Issues in Information Systems, 13(2), 193-200.

Alvarez Jr, A. V. (2020). The phenomenon of learning at a distance through emergency remote teaching amidst the pandemic crisis. Asian Journal of Distance Education, 15(1), 144-153.

Bączek, M., Zagańczyk-Bączek, M., Szpringer, M., Jaroszyński, A., \& Wożakowska-Kapłon, B. (2021). Students' perception of online learning during the COVID-19 pandemic: a survey study of Polish medical students. Medicine, 100(7), e24821.

Bakioğlu, B. \& Çevik, M. (2020). COVID-19 Pandemisi Sürecinde Fen Bilimleri Öğretmenlerinin Uzaktan Eğitime İliş̧kin Görüşleri. Electronic Turkish Studies, 15(4), 109-129.

Barker, B. S. (2002). Barker BS. (2002). A comparison research model for adult distributed training. Unpublished doctoral dissertation, University of Nebraska, Lincoln.

Barnett-Queen, T., Blair, R., \& Merrick, M. (2005). Student perspectives of online discussions: Strengths and weaknesses. Journal of Technology in Human Services, 23(3-4), 229-244.

Barbour, M. K., \& Reeves, T. C. (2009). The reality of virtual schools: A review of the literature. Computers \& Education, 52(2), 402-416.

Bozkurt, A. (2020). Koronavirüs (Covid-19) pandemi süreci ve pandemi sonrası dünyada eğitime yönelik değerlendirmeler: Yeni normal ve yeni eğitim paradigması. Açıkögretim Uygulamaları ve Araştırmaları Dergisi, 6(3), 112-142.

Bozkurt, A., \& Sharma, R. C. (2020). Emergency remote teaching in a time of global crisis due to CoronaVirus pandemic. Asian Journal of Distance Education, 15(1), 1-6.

Brereton, P. (2021). Emergency remote training: guiding and supporting teachers in preparation for emergency remote teaching. Language Research Bulletin (International Christian University, Tokyo), 35, 1-13.

Briggs, C. L. (1986). Learning how to ask: A sociolinguistic appraisal of the role of the interview in social science research (No. 1). Cambridge university press.

Can, E. (2020). Coronavirüs (Covid-19) pandemisi ve pedagojik yansımaları: Türkiye'de açık ve uzaktan eğitim uygulamaları. Açıkögretim Uygulamaları ve Araştırmaları Dergisi, 6(2), 11-53.

Çalık, E. Ö. \& Altay, I. F. (2021). Analysis of English lesson broadcasts during emergency remote teaching from pedagogical, instructional and technical aspects. International Journal of Education, Technology and Science, 1(2), 71-87. 
Demir, S. \& Kale M. (2020). Öğretmen görüşlerine göre, Covid-19 küresel salgını döneminde gerçekleştirilen uzaktan eğitim sürecinin değerlendirilmesi. Turkish Studies, 15(8), 3445-3470.

Dumford, A. D. \& Miller, A. L. (2018). Online learning in higher education: exploring advantages and disadvantages for engagement. Journal of Computing in Higher Education, 30(3), 452-465.

Durak, G. (2014). The effects of a distance education programming language course on student performance. Journal of Theory and Practice in Education, 10(1), 202-219.

Er-Türküresin, H. (2020). Covid-19 pandemi döneminde yürütülen uzaktan eğitim uygulamalarının öğretmen adaylarının görüşleri bağlamında incelenmesi. Milli Ĕ̆itim Dergisi, 49(1), 597-618.

Gilbert, S. (1999). How to be a successful online student. McGraw-Hill.

Glaser, B. G. (1965). The constant comparative method of qualitative analysis. Social

Hammond, T., Watson, K., Brumbelow, K., Fields, S., Shryock, K., Chamberland, J., Barroso, L., de Miranda, M., Johnson, M., Alexander, G., Childs, M. D., Ray, S., White, L., Cherian, J., Dunn, A., \& Herbert, B. (2020). A survey to measure the effects of forced transition to $100 \%$ online learning on community sharing, feelings of social isolation, equity, resilience, and learning content during the COVID-19 pandemic. Available electronically from http://hdl.handle.net/1969.1/187835.

Harris-Packer, J. D. \& Ségol, G. (2015). An empirical evaluation of distance learning's effectiveness in the K-12 setting. American Journal of Distance Education, 29(1), 4-17.

Hodges, C. B., \& Barbour, M. K. (2021). Assessing learning during emergency remote education. Italian Journal of Educational Technology, 29(2), 85-98.

Hodges, C., Moore, S., Lockee, B., Trust, T., \& Bond, A. (2020, March 27). The difference between emergency remote teaching and online learning. Educause Review. https://er.educause.edu/articles/2020/3/the-difference-between-emergency-remoteteaching-andonline-learning

Huang, M., Shi, Y. \& Yang, X. (2021). Emergency remote teaching of English as a foreign language during COVID-19: Perspectives from a university in China. International Journal of Educational Research and Innovation, 15, 400-418.

Kaiper-Marquez, A., Wolfe, E., Clymer, C., Lee, J., McLean, E. G., Prins, E., Stickel, T. (2020). On the fly: Adapting quickly to emergency remote instruction in a family literacy programme. International Review of Education, 66(5), 691-713.

Kathleen, A. J., \& Christopher, F. B. (2020). Students' responses to emergency remote online teaching reveal critical factors for all teaching. Journal of Chemical Education, 97(9), 2472-2485.

Khlaif, Z. N. \& Salha, S. (2020). The unanticipated educational challenges of developing countries in Covid-19 crisis: A brief report. Interdisciplinary Journal of Virtual Learning in Medical Sciences, 11(2), 130-134.

Khlaif, Z. N., Salha, S. \& Kouraichi, B. (2021). Emergency remote learning during COVID-19 crisis: Students' engagement. Education and Information Technologies, 26, 7033-7055.

Kong, J.E., Lee, D. (2021). A study on middle school students' perceptions on remote english learning during COVID-19. Journal of English Teaching through Movies and Media, 22(2), 41-57.

Means, B., Bakia, M. \& Murphy, R. (2014). Learning online: What research tells us about whether, when and how. Routledge.

Meyer, J. D. \& Barefield, A. C. (2010). Infrastructure and administrative support for online programs. Online Journal of Distance Learning Administration, 13(3), Retrieved from http:// www.westga.edu/ distance/ojdla/Fall133/index.php.

Mohmmed, A. O., Khidhir, B. A., Nazeer, A., \& Vijayan, V. J. (2020). Emergency remote teaching during Coronavirus pandemic: the current trend and future directive at Middle East College Oman. Innovative Infrastructure Solutions, 5(3), 1-11.

$\mathrm{Ng}$, C. (2019). Shifting the focus from motivated learners to motivating distributed environments: A review of 40 years of published motivation research in Distance Education. Distance Education. 40(4), 469-496.

Ng, W. \& Nicholas, H. (2010). A progressive pedagogy for online learning with high-ability secondary school students: A case study. Gifted Child Quarterly, 54(3), 239-251. 
Niemi, H. M., \& Kousa, P. (2020). A case study of students' and teachers' perceptions in a Finnish high school during the COVID pandemic. International Journal of Technology in Education and Science, 4(4), 352-369.

Patton, M. Q. (1987). How to use qualitative methods in evaluation. Sage.

Patton, M.Q. (2002). Qualitative research and evaluation methods (3rd Ed.). Sage.

Reiss, M. J. (2020). Science Education in the Light of COVID-19. Science \& Education, 29(4), 1079-1092.

Robinson, H. A., Al-Freih, M. \& Kilgore, W. (2020). Designing with care: Towards a care- centered model for online learning design. The International Journal of Information and Learning Technology, 37(3), 99-108.

Schlesselman, L. S. (2020). Perspective from a teaching and learning center during emergency remote teaching. American Journal of Pharmaceutical Education. 84(9), 11-29.

Shamir-Inbal, T. \& Blau, I. (2021). Facilitating emergency remote K-12 teaching in computing-enhanced virtual learning environments during COVID-19 pandemic-blessing or course?. Journal of Educational Computing Research, 59(7) 1243-1271.

Shim, T. E. \& Lee, S. Y. (2020). College students' experience of emergency remote teaching due to COVID-19. Children and youth services review, 119, Article 105578.

Shin, M., \& Hickey, K. (2021). Needs a little TLC: Examining college students' emergency remote teaching and learning experiences during COVID-19. Journal of Further and Higher Education, 45(7), 973 986.

Shrivastav, T. (2020). Emergency remote teaching in the times of CORONA pandemic. In S. Dhar, R. Shinde, S. Jain, N. Solomon (Ed.). Teaching and Learning Language and Literature in the Digital Era: Opportunities and Challenges (pp. 109-112). Excellent Publishing House.

Sosa Díaz, M. J. (2021). Emergency Remote Education, Family Support and the Digital Divide in the Context of the COVID-19 Lockdown. International Journal of Environmental Research and Public Health, 18, 7956.

Trentin, G. (2007). Pedagogical sustainability of network-based distance education in university teaching. In E. P. Bailey (Ed.). Focus on distance education developments (pp. 79-106). Nova Science Publishers Inc.

Uçar, H. \& Kumtepe, A. T. (2016). Uzaktan eğitimde ARCS-V motivasyon tasarımı modelinin kullanımı. Açıöğretim Uygulamaları ve Araştırmaları Dergisi, 2(4), 37-54.

UNESCO (2020a). COVID-19 education response.

https://en.unesco.org/covid19/educationresponse/globalcoalition

Wang, D. \& East, M. (2020). Constructing an emergency Chinese curriculum during the pandemic: A New Zealand experience. International Journal of Chinese Language Teaching, 1(1), 1-19.

Wegerif, R. (1998). The social dimension of asynchronous learning networks. Journal of Asynchronous Learning Networks, 2(1), 34-49. 
WHO. (2020a). Coronavirus disease (COVID-19) Pandemic. World health Organization. https://www.who.int/emergencies/diseases/novel-coronavirus-2019

WHO. (2020b). WHO Coronavirus Disease (COVID-19) Dashboard. World health Organization. https://covid19.who.int/

Wilcox, B. \& Vignal, M. (2020). Recommendations for emergency remote teaching based on the student experience. The Physics Teacher, 58, 374-375.

Yamamoto, G. T. \& Altun, D. (2020). Coronavirüs ve çevrimiçi (online) eğitimin önlenemeyen yükselişi. Üniversite Araştırmaları Dergisi, 3(1), 25-34.

Yates, A., Starkey, L., Egerton, B., \& Flueggen, F. (2021). High school students' experience of online learning during Covid-19: the influence of technology and pedagogy. Technology, Pedagogy and Education, 30(1), 59-73.

Yıldız, E. \& Seferoğlu, S. S. (2020). Uzaktan eğitim öğrencilerinin çevrim içi teknolojilere yönelik öz yeterlik algılarının incelenmesi. Celal Bayar Üniversitesi Sosyal Bilimler Dergisi, 18 (1), 33-46.

Zhang, W., Wang, Y., Yang, L., \& Wang, C. (2020). Suspending classes without stopping learning: China's education emergency management policy in the COVID-19 outbreak. Journal of Risk and Financial Management, 13 (55), 2-6.

Zilka, G. C., Cohen, R. \& Rahimi, I. D. (2018). Teacher presence and social presence in virtual and blended courses. Journal of Information Technology Education: Research, 17, 103-126. 